\title{
Article
}

\section{Building strategic resilience in food supply chain}

Manning, Louise and Soon, Jan Mei

Available at http://clok.uclan.ac.uk/18001/

Manning, Louise and Soon, Jan Mei ORCID: 0000-0003-0488-1434 (2016)

Building strategic resilience in food supply chain. British Food Journal, 118 (6). pp. 1477-1493. ISSN 0007-070X

It is advisable to refer to the publisher's version if you intend to cite from the work. http://dx.doi.org/10.1108/BFJ-10-2015-0350

For more information about UCLan's research in this area go to

http://www.uclan.ac.uk/researchgroups/ and search for < name of research Group>.

For information about Research generally at UCLan please go to http://www.uclan.ac.uk/research/

All outputs in CLoK are protected by Intellectual Property Rights law, including Copyright law. Copyright, IPR and Moral Rights for the works on this site are retained by the individual authors and/or other copyright owners. Terms and conditions for use of this material are defined in the policies page.

\section{CLoK}

Central Lancashire online Knowledge www.clok.uclan.ac.uk

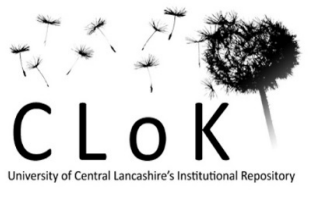




\section{Building strategic resilience in the food supply chains}

\begin{tabular}{|r|l|}
\hline Journal: & British Food Journal \\
\hline Manuscript ID & BFJ-10-2015-0350.R2 \\
\hline Manuscript Type: & Research Paper \\
\hline Keywords: & Benchmarking, indicators, Stakeholders, Value, performance \\
\hline \multicolumn{2}{|c}{} \\
\hline
\end{tabular}

SCHOLARONE $^{\text {m }}$

Manuscripts 


\section{Abstract}

Purpose: The aim of this paper is to consider the concept of strategic business resilience in order to postulate innovative mechanisms to drive business performance in the food supply

7 chain.

8 Design: The research included a literature review and the development of a resilience model

9 that can be adopted in the food supply chain at both a strategic and an operational level.

10 Findings: Conflict of interest exist for organisations that are seeking to strategically and 11 effectively manage the pluralistic nature of internal and external supply chain risks. The 12 model derived in this research can be used in the food supply chain to drive supply chain 13 agility, organisational stability and longevity, and as a result continuous improvement.

14 Originality/value - This research is of academic value and of value to policy makers and 15 practitioners in the food supply chain.

16

Keywords benchmarking, performance, indicators, stakeholders, value

\section{Introduction}

22 as the capacity to absorb market and environmental shocks and still maintain a fully

23 functioning food supply chain (Folke, 2006). Factors that influence food supply chains 24 include: natural disasters, technological accidents, infectious diseases, terrorism, and food 25 safety incidents (Leat and Revoredo-Giha, 2013), food fraud and wider food crime and 26 market and pricing strategies. Factors that affect supply chain resilience can be internal i.e.

27 within the supply chain network or external factors often outside the control of the 28 organisations involved. These factors can be categorised as: processes such as transport, 29 communication and infrastructure; controls including protocols, policies, procedures, systems 
30 and assumptions; and demand and supply related issues such as the fear of, or actual

31 disturbances to, the multi-directional flow of materials, product, finance and information

32 (Christopher and Peck, 2004). Driving a business strategy focused primarily on cost reduction 33 without sufficient regard for the risks that this strategy creates will make the food supply 34 chain more brittle (Viswanadham and Kameshwaran, 2013; Waters, 2007). Food supply chain 35 brittleness is centred on factors such as low financial margins, low profitability and low 36 resource stocks i.e. a lean management approach that can combine in multiple ways with 37 social factors (e.g. consumer trust and brand loyalty) and factors such as weather vulnerability 38 that affects quality or yield, price volatility or natural variation. The degree of financial 39 brittleness in a particular food supply chain will depend on the level of profitability, liquidity, 40 the ability to meet loan repayments and continue to implement capital investment plans that 41 underpin business growth. Ultimately, lower operating margins reduce financial flexibility 42 and create a more brittle supply chain that is vulnerable to major risks such as animal disease, 43 volatility in commodity markets and an increasing cost of legal and/or social compliance.

44 Conversely, food supply chain agility is determined by the level of financial return, 45 efficiency, innovation, resource management and the ability to have alternative sourcing 46 mechanisms in place for key ingredients, organisational responsiveness and underpinning 47 product quality that consistently meets customer requirements. For resilience to be assured in 48 the food supply chain brittle structural aspects need to be effectively managed and where 49 possible agility enhanced. Thus, it can be questioned whether the single concept of social50 ecological food supply chain resilience is normative (Keessen et al. 2013) or if there are 51 multiple meanings for what it is for an organisation, a discrete supply chain or indeed the 52 whole global food system to be deemed as being resilient. There is heterodoxy in the 53 vocabulary surrounding the meanings of resilience (Table 1) from it being the opposite of 54 vulnerability (Folke, 2006: Levina and Tirpak, 2006) to the ability to return to a stable state 
55 i.e. business as usual (Morecroft et al. 2012; Holling et al. 1996; Pimm, 1991) through to the 56 capacity for change, growth, and renewal. Folke (2006:259) suggests that resilience needs to 57 embrace "the opportunities that disturbance opens up in terms of recombination of evolved structures and processes, renewal of the system and emergence of new trajectories".

\section{Take in Table 1}

60

Five drivers identified by Foresight (2011) that will propel change in global food supply chains are: global population increase; change in the size and nature of per capita demand for food especially for meat and fish; climate change; competition for key resources (land, water and energy); and changes in values and ethical stances of consumers. Folke (2006) determines three concept of resilience: engineering resilience, ecological and socio-ecological resilience and this has been adapted to the food supply chain (Table 2). Engineering resilience is a transactional concept where the focal point for management is task-orientated and is one of recovery, constancy, and continuity. Ecological resilience considers the ability to withstand business shock requiring aspects of management such as persistence and robustness whilst

70 socio-ecological resilience reflects transformational aspects of management that encompass 71 learning, innovation and dynamic development. This self-organising process is in essence the 72 equilibrium that is derived from reorganising, evolving and adapting as an organisation to the

73 wider socio-economic environment that it operates in. Buffer capacity (also a key 74 characteristic of ecological resilience) is the ability for an organisation or a supply chain to 75 withstand shock and remain as a fully functioning business. Examples of how buffer capacity 76 can be built is the use of buffer material and product stocks, or analysis of required skillsets 77 for the organisation and a programme of capacity building in individuals through training and 78 development. Thus, food supply chain resilience can be described and organisational goals 79 can be developed either transactionally using financial, quantitative metrics or qualitatively in 
80 terms of the ecological or holistic properties of resilience interfacing with what would

81 generally be considered to be elements of an organisation's corporate social responsibility 82 (CSR) strategy. However, organisations are increasingly expected to review their ethical 83 performance in relation to stakeholders' expectations, identify how improvements could be 84 made and then communicate these deliberations back to their stakeholders in order to deliver 85 continued value (Manning et al. 2006; Manning, 2015). The whole process of value creation 86 in food supply chains is realised through multi-organisational involvement and building 87 mutual benefit (Caiazza and Volpe, 2012). Further they argue that a value chain is in fact an 88 economic and social reality involving a set of actors and activities that interact and work 89 together to satisfy the needs of specific markets. This definition supports the socio-economic 90 view of strategic resilience (Caiazza et al. 2014; Caiazza and Volpe, 2012).

91 Whilst exploitation of natural resources could be considered as a key element of a global 92 multinational corporation's (MNC) model of operation, this can create ecologically defined 93 market failures in resource rich developing nations especially as a result of soil and 94 groundwater depletion, reduction in forested areas etc. (Stigliz, 2006). An organisation can 95 seek to offset the environmental impact of these activities by a variety of means e.g. reducing 96 waste, using emissions or outputs from one process as inputs into another, offsetting 97 emissions by developing other sequestering activities. However, this stratagem focuses on 98 mitigation of current practice rather than innovating and adapting the whole process to embed 99 long term organisational resilience. Organisational ability to adapt to change can stall if there 100 are high levels of complexity in terms of products, processes and intra- and inter101 organisational structures (Power, 2005). Therefore, organisational resilience is to be the 102 ability to reinvent dynamically business models and associated corporate strategies as 103 circumstances change (Hamel and Välikangas, 2003). Ultimately, resilience must be 104 embedded strategically and within the operating system, driving agility, an ability to be 
105 adaptive and deliver solutions especially with regard to emerging or re-emerging risks. The 106 aim of this paper is to consider the concept of strategic business resilience in order to 107 postulate innovative mechanisms to drive business performance in the food supply chain.

\section{2. Strategic and operational resilience}

109 Resilience is in part "the ability of an organisation to approach crisis situations as a 110 potentially positive experience, and to utilise an enhanced ability to change as the economic, 111 physical, political and social situation demands" (McManus, 2008:26). Strategic resilience is 112 not about responding to a single crisis or rebounding from a setback, it encompasses 113 anticipating and reacting to secular trends that can permanently impair the earning power of 114 the core business (Hamel and Välikangas, 2003). Alternatively it has been suggested that 115 strategic resilience "results when the organisation gains the capability to quickly convert 116 threatening surprises into opportunities and to identify unique opportunities and act 117 effectively before their competition" (Välikangas and Romme 2012:45). Further Välikangas 118 and Romme (2012) differentiate between operational resilience and strategic resilience where 119 the former is recovery focused e.g. after experiencing a crisis and tenacity in the face of threat 120 i.e. reactive management and the latter is renewal focused in terms of changing without the 121 driver of a crisis i.e. proactive management. The research has considered the concept of 122 strategic and operational business resilience and postulated that innovative mechanisms need 123 to be developed in order to embed resilience and drive performance and continuous 124 improvement in the food supply chain.

125 Development of risk management strategies is a core executive process. Shareholders will 126 place specific emphasis on ensuring the inherent risk to their financial investment is addressed 127 in the strategic planning processes undertaken by senior management executives and 128 executive boards. Indeed definition of organisational risk and the means for its control forms 129 part of an executive annual report. A formulated approach has been described (Mintzberg, 
130 1978) where internal risks associated with the organisation itself should be easier to quantify

131 and thus mitigate than external risk (national or global social, political or economic forces)

132 especially where there is a strong organisational operating system in place. Management can

133 alleviate the effect of such risks by developing a risk register and then having contingency or

134 disaster recovery strategies in place, but such a formulated, executive approach may still not

135 react quickly enough to a sudden supply chain "shock" or an emergent, previously unknown

136 risk. Strategic change is often by its nature ad hoc and irregular, never steady and results from

137 the interaction of periods of continuity, change, flux and inertia (Mintzberg, 1978).

138 Ensuring resilience in a wider business environment that is evolving rapidly requires two

139 kinds of strategy firstly intended strategy i.e. what was planned and, secondly what is realised

140 strategy i.e. what happened in practice. This emergent strategy is actually, what is exhibited

141 by the organisation (Figure 1).

\section{Take in Figure 1}

143 Business continuity management $(\mathrm{BCM})$ is the management process that identifies an

144 organisation's exposure to internal and external threats and as a result synthesizes hard and

145 soft assets to provide effective prevention and recovery for the organisation i.e. operational

146 resilience, whilst maintaining competitive advantage and value system integrity namely

147 strategic resilience (Elliott et al. 2002). Operational BCM should be driven by an interactive

148 rather than a purely reactive or proactive strategy and during contingency planning

149 consideration should be given to ensure that plans developed in isolation can be actualised

150 whether they are needed or not (Elliott et al. 2002; Mintzberg, 1978). The scope of

151 contingency plans in the food supply chain can include factors such as natural disaster,

152 climate variation, flood, fire, crop failure, yield reduction, animal disease outbreak, and

153 failure of product to meet minimum quality specifications. Product recall, foodborne disease

154 outbreak, supply chain failure (bankruptcy or financial failure of supply chain partners, 
155 logistical failure), food crime, threat or supply chain sabotage, and disruption to services e.g. 156 internet, electricity, waste disposal, water, and distribution networks as with the historic 157 incident of volcanic ash preventing movement of air freighted food should also be considered. 158 Transactional consideration of engineering resilience in the context of BCM reflects the time 159 to return to a stable state following shock, or perturbation, i.e. how quickly supply can be 160 resumed (Folke, 2006; Morecroft et al. 2012), but this is limited in terms of the socio161 ecological resilience requirements of creating supply chain value. This latter, self-organising, 162 approach drives the interplay between supply chain disturbance, reorganising, sustaining and 163 developing i.e. continuous improvement through enhancing adaptive capacity. In this context, 164 the focal point for management is facilitating transformability, learning, and innovation rather 165 than recovery or constancy. This requires fully integrated feedback systems and cross-chain 166 dynamic interactions between organisations (Table 2). In order to develop an appropriate 167 business continuity plan (BCP) that ensures strategic and operational resilience, consideration 168 must be given to the environment in which the BCP will operate, and to the degree of 169 turbulence in terms of the rate of change that is externally or internally driven. Therefore, the 170 strategy must be flexible, and include the ability to deliver a set of value-based aspirations. 171 Organisations need to consider resilience as being well beyond a BCP and develop strategies 172 that, as Mintzberg (1978) describes, are not just formulaic but allow for an iterative approach 173 to maintaining resilience. This requires management focus not to be purely on the 174 organisational process and the architectural framework of policies, protocols and systems 175 (system measures as defined by Tangen, 2005) but go further to consider how performance 176 measures can be developed that will inform and lead strategy.

177 In determining risk, there are a number of factors that can be considered including marketing 178 and pricing strategies, food safety incidents, food fraud and food crime, infections livestock 179 diseases, technological and infrastructure risks and national and localised natural disasters or 
180 accidents (see Figure 2). These will have an impact on strategic resilience in terms of both 181 market and technology turbulence. Market turbulence is determined as the change in the 182 composition of customers and their preferences whereas technological turbulence refers to the 183 amount and unpredictability of change in production or service technologies (Slater and 184 Narver (1994) cited by Terawatanavong et al. 2011). Market and technology turbulence can 185 have both a push dynamic (from the challenges at primary production in terms of natural 186 resource availability, livestock disease outbreak, weather and seasonal impacts, influence of 187 ability to freely distribute product) through to a pull dynamic by the consumer. Primary level 188 food production is subject to a number of potential "shocks" that can cause poor yields or 189 crop failure either on an acute level in a single year or have chronic effects over a number of 190 years, even decades. These factors can often have more influence in terms of supply and 191 demand dynamics than ongoing technological research work in continuously developing the 192 genetic potential of the crop to yield (Ray et al. 2012). Due to multiplier factors, poor feed 193 crop yield and low product quality at primary production level impacts on further stages in the 194 food supply chain e.g. the escalating effect, in terms of net efficiency, of poor feed quality and 195 then lower feed conversion rate in the animals the feed is provided for. In food supply chains 196 accumulative weak performance will influence food availability, and affordability for the 197 world's increasingly urban population with an aggregation of marginal losses, rather than 198 marginal gains. The aggregation of marginal gains theory is that multiple, seemingly 199 miniscule, improvements throughout any given process, can collectively achieve a far 200 superior output (Durrand et al. 2014; Eisen et al. 2014; Hill, 2014; Smith et al. 2014). 201 Conversely the aggregation of marginal losses theory is worthy of consideration in the wider 202 context of resilience and supply chain performance.

203 Assurance of strategic and operational resilience requires the integrated engagement of supply 204 chain actors at all stage of food production, distribution and information exchange in order to 
205 limit vulnerability, external and internal risks. Threat Assessment Critical Control Point 206 (TACCP) is described in PAS 96 (2014:3) as the "systematic management of risks through 207 the process of assessment of threats, identification of vulnerabilities, and implementation of 208 controls to raw materials, packaging, finished products, processes, premises, distribution 209 networks and business systems by a knowledgeable and trusted team with the authority to implement changes to procedures". Thus, an appropriate and well-integrated TACCP plan is 211 just one element of a wider strategic resilience risk assessment that can be undertaken from 212 primary production through to the consumer. In order to drive a quantitative approach to 213 strategic resilience risk assessment, an architecture of analysis needs to be clearly defined, 214 although the architecture must be agile enough to accommodate sudden and unexpected 215 supply shocks in the event that they occur. Ultimately, corporate goals should be formulated 216 and these need to cascade into specific, relevant and time bound measures. These measures 217 can be strategic and influence the whole supply chain e.g. a supply chain level approach to 218 reducing waste or be operationally based measures that define performance at a single supply 219 chain stage. These corporate goals will as a result have influence either as a whole chain actor 220 or as a single stage actor. Interest in CSR benchmarking for demonstrating social and 221 environmental performance has promoted the development of supply chain guidelines and 222 codes of practice (Manning and Baines, 2004). Benchmarking as an activity can then monitor 223 the degree of integration between different measures and the actual organisational and/or 224 supply chain performance that is realised. The use of methods to construct and to assess 225 measureable socio-ecological indicators has been proposed (Mitchell et al. 1995; Hansen 226 1996; Bockstaller et al. 1997; Rigby et al. 2001; Hak et al. 2012). This approach suggests that 227 quantitative measures can be used to drive what for many are deemed qualitative social 228 aspirations and when the use of qualitative and semi-quantitative measures is open to 229 interpretation. Bell and Morse (2003) stated that supply chain performance indicators must be 
230 specific (outcome bound); quantitative (measureable): usable (of practical value); available 231 (data easily collated); cost-effective (not expensive to collect); and sensitive (demonstrate 232 changes in circumstances). This does not preclude the use of qualitative indicators, but by 233 their nature, qualitative indications do not drive business performance and continuous 234 improvement in the same way as quantitative indicators. Bourlakis et al. (2014) differentiate 235 between four categories of socio-ecological supply chain indicators (efficiency, flexibility, 236 responsiveness and product quality). In Table 3, the work of Bourlakis et al. 2014 has been 237 adapted for the four factors with consideration of economic, environmental and social 238 characteristics that they can quantify. Consideration of this work highlights that a resilience 239 indicator framework could be developed that can be used at a strategic level or an operational 240 level to provide socio-economic organisational and supply chain measures that define 241 business goals and objectives which are measureable i.e. quantitative.

\section{Take in Table 3}

244 Benchmarking is the means by which targets, priorities and operations are established that 245 will lead to competitive advantage (Oakland, 1993). Lau et al. (2005) characterise 246 benchmarking as the systematic comparison of elements of performance in a company against 247 those best practices of relevant companies, and then obtaining information that will help the 248 observing company to identify and implement improvement. In order for benchmarking to be 249 effective, it requires a measured consideration of whether the process will be implemented 250 either at a strategic management level or at an operational, activity or enterprise level, or both.

251 To reflect on this in another way, the benchmarking approach to developing resilience can be 252 designed to underpin BCM strategies, long term strategic aims and objectives at the supply 253 chain, or product category scale, as well as operationally drive the implementation of a CSR 254 strategy or simply provide baseline data and then drive improvement. Synthesizing the 
255 literature reviewed in this study as Hamel and Välikangas (2003) propose strategic resilience 256 is not about simply responding to a single crisis or rebounding from a setback. Strategic 257 resilience considers, anticipates and mitigates pressures, and drivers that influence the socio258 economic environment in which the business operates. The factors considered are strategic 259 leadership, strategic decision-making, supply chain dynamics, value based dynamics and the 260 use of performance indicators in the context of external and internal influences and at the 261 executive, organisational and individual level (Table 4).

\section{Take in Table 4}

263

264 Building on Table 4 and utilising the so-called 3Rs (ready-respond-recover) approach to 265 resilience proposed by Ponomarov and Holcomb (2009) a 3Rs strategic resilience risk 266 assessment framework for the food supply chain has been developed (Figure 2). This 267 framework via consideration of internal organisational and external supply chain risks, and 268 the ability of an individual organisation or a food supply chain to ready, respond and recover. 269 Six examples of risk are illustrated in the framework, although this is not an exhaustive list, 270 namely natural disasters, technological accident and infrastructure threats, infection or 271 disease, food fraud and wider food crime, food safety incidents, outbreaks and product recalls 272 and marketing and pricing strategies. The strategic resilience risk assessment framework 273 identifies industry risk assessment tools that are already utilised to determine risk, TACCP 274 with regard to food fraud and wider food crime and hazard analysis critical control point 275 (HACCP) which is an approach used to consider food safety risk and its mitigation.

\section{Take in Figure 2}

277

278 Supply chain relationships depend on the abilities of the individual organisations in the food 279 supply chain to individually and collectively act efficiently, flexibly, in order to be agile, 
280 responsive and meet the complicated customer specifications for their products and services 281 each time. This requires a hierarchy of strategic resilience aims and objectives and an 282 architecture of analysis to be built around the supply chain metrics that are developed

283

284

285

In the context of a generic food supply chain, a conceptual resilience indicator framework 286 (Figure 3) has been proposed using the secondary processing stage as an example. Similar 287 strategic resilience indicator frameworks can be developed for other stages of the food supply 288 chain, bespoke to particular products, processes or scenarios. The framework also includes a 289 range of indicators that can be used as part of a supply chain monitoring process to create 290 value for the organisation itself improving its strategic and operational resilience and provide 291 value for a range of stakeholders. These stakeholders include shareholders who may reflect on 292 their being less financial risk and a greater underpinning of brand value, insurance companies 293 who are requested to provide insurance against risks such as product recalls, stock rejection, 294 etc. and supply chain partners, community groups and consumers who may each define 295 supply chain value in their own distinct ways. The use of a strategic resilience indicator 296 framework can provide opportunity for an organisation to address internal and external risk 297 and mitigate such risk wherever possible. This approach is of value to practitioners in the 298 food supply chain in order to reduce risk. Risk is determined at many levels in an organisation 299 from executive risk registers in corporate documents to the development of BCM protocols 300 and the use of TACCP and HACCP at an operational level as described in the paper. The 301 resilience assessment tools explored in this research can assist practitioners to consider a more 302 integrated approach to managing risk and developing strategic resilience management 303 programmes. 
306

307

308

309

310

311

312

313

314

315

316

317

318

319

320

321

322

323

324

325

326

327

328

329

330

331

332

333

334

335

\section{Conclusion}

The aim of this paper is to consider the concept of strategic business resilience in order to postulate innovative mechanisms to drive business performance in the food supply chain. A 3Rs (ready, respond and recovery) business resilience risk assessment framework and an associated resilience indicator framework has been developed to enable organisations in the food supply chain to determine and improve their strategic resilience in terms of both internal organisational and external supply chain risk factors. This incorporates the five strategic resilience factors (values-based dynamics, supply chain dynamics, strategic decision-making, strategic leadership, and use of performance indicators) into the 3Rs strategic resilience risk assessment framework (Figure 3) to identify ways to ensure readiness through formal procedures and protocols, effective response and recovery. The strategic resilience indicator framework (Figure 4) can be use to develop and utilise performance indicators that demonstrate the degree of vulnerability within the socio-economic environment in which the organisation operates. Conflict of interest exists for organisations that are seeking to strategically and effectively manage the pluralistic nature of internal and external supply chain risks. The model derived in this research can be used in the food supply chain to drive supply chain agility, organisational stability and longevity, and as a result continuous improvement.

\section{References}

Ackoff, R.L. (1990), Strategy: Redesigning the Future, Systems Practice, 3 (6): 521-524

Adger, W. N. (2006), Vulnerability. Global Environmental Change, Vol. 16, Iss. 3, pp. 268281.

\section{Bell, S., and Morse S. (2003), Measuring sustainability: learning by doing, Earthscan} Publications Ltd, London

Berkes, F., Colding, J., and Folke, C. (Eds.), (2003). Navigating Social-Ecological Systems: Building Resilience for Complexity and Change. Cambridge University Press, Cambridge, UK. 
336 Bockstaller, C., Cirardin, P. and van der Werf, H.M.G. (1997), Use of agro-ecological

337 indicators for the evaluation of farming systems. European Journal of Agronomy, Vol. 7, Iss.

338 1-3, pp. 261-270.

339

340

341

342

343

344

345

346

347

348

349

350

351

352

353

354

355

356

357

358

359

360

Bourlakis, M., Maglaras, G., Gallear, D. and Fotopoulos, C. (2014), Examining sustainability performance in the supply chain: The case of the Greek dairy sector, Industrial Marketing Management, Vol. 43, Iss. 1. pp. 56-66.

Caiazza R., and Volpe T., (2015), Interaction despite of diversity: Is it possible? Journal of Management Development, Vol.34, Iss. 6. pp. 743-750

Caiazza R., Volpe T., and Audretsch D.B., (2014), Innovation in Agro-food System: Policies, actors and activities, Journal of Enterprising Communities: People and Places in the Global Economy, Vol. 8, Iss.3, pp. 180-187

Caiazza R., and Volpe, T. (2012), The Global Agro-food system from past to future, ChinaUSA Business Review, Vol. 11, No 7. Pp. 919-929

Christopher, M. and Peck, H. (2004), Building the resilient supply chain, International Journal of Logistics Management, Vol. 15, Iss. 2, pp. 1-13

Delmas, M., and Burbano, V.C. (2011), The Drivers of Greenwashing, California Management Review, Vol. 54, Iss. 1, pp. 64-87.

361

Driessen, P.P.J, and Van Rijswick, H.F.M.W. (2011), Normative aspects of climate adaptation policies. Climate Law, Vol. 2, Iss. 4, pp. 1-23 $\square$

362 Durrand, J.W., Batterham, A.M. and Danjoux, G.R. (2014), Pre-habilitation (i): aggregation 363 of marginal gains, Anaesthesia, Vol. 69, Iss. 5, pp. 403-406

364 Eisen, S., van der Poel, L., Clough, L., Musial, M., Walsh, O., and Salt, P. (2014), G183 365 Improving the patient pathway: aggregation of marginal gains in a secondary paediatric 366 allergy service, Srch Dis Child, Vol. 99, Iss. Suppl 1. p187 doi:10.1136/archdischild-2014$367 \quad 306237.187$

368

369

370

371

372

Elliott, D., Swartz, E., and Herbane, B. (2002), Business Continuity Management. A crisis management approach, Routledge, Oxon.

Folke, C. (2006), Resilience: the emergence of a perspective for social-ecological systems analyses. Global Environmental Change Vol.16, Iss. 1, pp. 253-267.

373 Foresight. The Future of Food and Farming (2011) Executive Summary. The Government 374 Office for Science, London.

375

376 Gunderson, L., and S. S. Light. 2006. Adaptive management and adaptive governance in the 377 Everglades ecosystem. Policy Sciences Vol. 39, Iss. 4, pp. 323-334.

378 Gunderson, L.H., and Holling, C.S. (Eds.), (2002). Panarchy: Understanding Transformations 379 in Human and Natural Systems. Island Press, Washington DC. 
Hak, T., Kovanda, J. and Weinzettel, J. (2012,) A method to assess the relevance of sustainability indicators: Application to the indicator set of the Czech Republic's Sustainable

Hamel, G., and Välikangas, L., (2003), The Quest for Resilience, Harvard Business Review, September 2003.

Hansen, J.W. (1996), Is agricultural sustainability a useful concept? Agricultural Systems, Vol. 50, Iss. 2, pp. 117-143.

Hill, J. (2014), Follow up after curative colorectal cancer resection - aggregation of marginal gains, Colorectal Disease, Vol 16. Iss. 8, pp. 575-576

Holling, C.S. (1996). Engineering resilience versus ecological resilience. In: Schulze, P. (Ed.), Engineering Within Ecological Constraints. National Academy Press, Washington DC, pp. 31-44.

Keessen, A. M., Hamer, J.M., Van Rijswick, H.F.M.W., and Wiering, M. (2013), The concept of resilience from a normative perspective: examples from Dutch adaptation strategies.

Ecology and Society, Vol. 18, Iss. 2 art. 45 http://dx.doi.org/10.5751/ES-05526-180245

Lau, H.C.W., Lau, P.K.H., Fung, R.Y.K., Chan, F.T.S. and Ip, R.W.L. (2005), A virtual case benchmarking scheme for vendors' performance assessment, Benchmarking: An International Journal, Vol. 12, Iss. 1, pp. 61-80.

Leat, P. and Revoredo-Giha, C. (2013), Risk and resilience in agri-food supply chains: the case of the ASDA PorkLink supply chain in Scotland. Supply Chain Management: An International Journal, Vol. 18 , Iss. 2, pp. 219-213.

Levina, E., and Tirpak, D. (2006), Adaptation to climate change: key terms. Organisation for Economic Co-operation and Development, Paris, France.

Manning, L. (2015), Determining value in the food supply chain, British Food Journal, Vol. 117, Iss. 11, pp. 1-17

Manning, L., Baines, R.N., and Chadd, S.A. (2006), Ethical modelling of the food supply chain, British Food Journal, Vol. 108, Iss. 5, pp. 358-370

Manning, L., and Baines, R.N. (2004), Globalisation: A study of the poultry meat supply chain, British Food Journal, Vol. 106, Iss. 10/11, pp. 819-836.

McManus, S.T (2008), Organisational resilience in New Zealand, Available at: http://www.resorgs.org.nz/images/stories/pdfs/organisational $\% 20$ resilience $\% 20 \mathrm{in} \% 20$ new $\% 2$ 0zealand.pdf [Accessed on: 29.12.15]

Mintzberg, H. (1978), Patterns in Strategy Formation, Management Science, Vol. 24, Iss. 9 pp. 934-948

Mitchell, G., May, A. and McDonald, A. (1995), PICABUE: a methodological framework for the development of indicators of sustainable development, International Journal of Sustainable Development and World Ecology, Vol. 2, Iss. 2, pp. 104-123. 
429

430

431

432

433

434

435

436

437

438

439

440

441

442

443

444

445

446

447

448

449

450

451

452

453

454

455

456

457

458

459

460

461

462

463

464

465

466

467

468

469

470

471

472

473

474

475
Morecroft. M.D., Crick, H.Q.P., Duffield, S.J., and Macgregor, N.A. (2012), Resilience to climate change: translating principles into practice, Journal of Applied Ecology, Vol. 39, Iss. 1, pp. 547-551

Muthuri, J., Moon J., and Matten, D. (2006), Employee Volunteering and the Creation of Social Capital, Research Paper Series. International Centre for Corporate Social Responsibility No. 34-2006 - ISSN 1479-5124.

Oakland J.S. (1993), Total Quality Management: The route to improving performance. Butterworth-Heinemann Ltd, Oxford.

PAS 96 (2014), Guide to protecting and defending food and drink from deliberate attack,ISBN978 058085537 5BSI Standards Limited

Pimm, S.L. (1991). The Balance of Nature? Ecological Issues in the Conservation of Species and Communities. University of Chicago Press, Chicago.

Ponomarov, S. Y. and Holcomb, M. C. (2009). Understanding the concept of supply chain resilience. International Journal of Logistics Management, Vol. 20, Iss. 1, pp. 124-143.

Power, D. (2005), Supply chain management integration and implementation: a literature review, Supply Chain Management: An International Journal, Vol.10, Iss. 4, pp. 252-63

Ray, D.K., Ramankutty, N., Mueller, N.D, West, P.C., and Foley, J.A. (2012), Recent patterns of crop yield growth and stagnation, Nature Communications, Vol. 3 (1293) Published 18.12.12 doi:10.1038/ncomms2296

Rigby. D., Woodhouse, P., Young, T. and Burton, M. (2001), Constructing a farm level indicator of sustainable agricultural practice, Ecological Economics, Vol. 39, Iss. 3, 463-478

Slater S.F., and Narver, J.C. (1994), Does competitive environment moderate the market orientation-performance relationship? Journal of Marketing, Vol. 58, No.1, pp. 46-55.

Smith, J., Meng, Z.W., Lockyer, R., Dudderidge, T., McGrath, J., Hayes, M., and Birch, B. (2014), Evolution of the Southampton Enhanced Recovery Programme for radical cystectomy and the aggregation of marginal gains, BJU International, Vol. 114, Iss. 3, pp. 375-383

Stigliz, J.E. (2006), Making Globalization Work, Allen Lane. ISBN 139780713999099

Tangen S. (2005), Insights from practice. Analysing the requirements of performance measurement systems, Measuring Business Excellence, 9 (4): 46-54

Terawatanavong, C., Whitwell, G.J., Widing, R.E., and O”Cass, A. (2011), Technological turbulence, supplier market orientation, and buyer satisfaction, Journal of Business Research, Vol. 64, Iss. 1, pp. 911-918

Välikangas, L.A. and Romme, G.L. (2012), Building resilience capabilities at "Big Brown Box, Inc.", Strategy \& Leadership, Vol. 40 Iss: 4 pp. 43 - 45 
1

2

3

4

5

6

7

8

9

10

11

12

13

14

15

16

17

18

19

20

21

22

23

24

25

26

27

28

29

30

31

32

33

34

35

36

37

38

39

40

41

42

43

44

45

46

47

48

49

50

51

52

53

54

55

56

57

58

59

60

476 Viswanadham, N., and Kameshwaran, S., (2013), Ecosystem-Aware Global Supply Chain 477 Management, World Scientific Publications.

478 Walker, B.H., Holling, C.S., Carpenter, S.R., Kinzig, A.P., (2004). Resilience, adaptability 479 and transformability in social-ecological systems. Ecology and Society, Vol. 9, Iss. 25.

480 [online] URL: http://www.ecologyandsociety.org/vol9/iss2/art5/

481

482 Waters, D. (2007), Supply Chain Risk management: Vulnerability and resilience in logistics, 483 ISBN: 9780749448547

484 
Table 1. Meanings of resilience (Adapted from Keessen et al. 2013; Folke 2006 and others)

\begin{tabular}{|l|l|}
\hline \multicolumn{1}{|c|}{ Meaning } & \multicolumn{1}{|c|}{ Source: } \\
\hline The opposite of vulnerability. & Folke, 2006; Levina and Tirpak, 2006 \\
\hline $\begin{array}{l}\text { A criterion to evaluate the quality of a strategy for adaptation to a } \\
\text { stimulus e.g. climate change. }\end{array}$ & $\begin{array}{l}\text { Adger, 2006; Driessen and Van Rijswick } \\
2011\end{array}$ \\
\hline $\begin{array}{l}\text { Ability of a system to adapt to change, but also the ability of a system } \\
\text { to persist despite change. }\end{array}$ & Gunderson and Light, 2006 \\
\hline $\begin{array}{l}\text { Ability of a system to return to its original state or move to a new, } \\
\text { more desirable state after being disturbed. }\end{array}$ & Christopher and Peck, 2004 \\
\hline The time to return to a stable state following shock, or perturbation. & $\begin{array}{l}\text { Morecroft } \text { et al. 2012; Holling 1996; } \\
\text { Pimm 1991 }\end{array}$ \\
\hline Capacity for renewal, re-organisation and development. & $\begin{array}{l}\text { Berkes } \text { et al. 2003; Gunderson and } \\
\text { Holling, 2002 }\end{array}$ \\
\hline $\begin{array}{l}\text { The amount of disturbance a system can take before its controls shift } \\
\text { to another set of variables and relationships that dominate another } \\
\text { stability region. }\end{array}$ & Folke, 2006 \\
\hline $\begin{array}{l}\text { The capacity of a system to absorb disturbance and re-organise while } \\
\text { undergoing change so as to still retain essentially the same function, } \\
\text { structure, identity and feedbacks. }\end{array}$ & Walker et al. 2004 \\
\hline
\end{tabular}

487

\begin{tabular}{|l|l|l|l|}
\hline \multicolumn{1}{|c|}{$\begin{array}{c}\text { Resilience } \\
\text { concepts }\end{array}$} & \multicolumn{1}{|c|}{ Characteristics } & \multicolumn{1}{c|}{$\begin{array}{c}\text { Focal point for } \\
\text { management }\end{array}$} & \multicolumn{1}{c|}{ Context } \\
\hline $\begin{array}{l}\text { Engineering } \\
\text { resilience }\end{array}$ & $\begin{array}{l}\text { Transactional: return time, } \\
\text { efficiency }\end{array}$ & Recovery, constancy & $\begin{array}{l}\text { Stable equilibrium i.e. } \\
\text { returning to a steady } \\
\text { state. }\end{array}$ \\
\hline $\begin{array}{l}\text { Ecological } \\
\text { resilience }\end{array}$ & $\begin{array}{l}\text { Buffer capacity: ability to withstand } \\
\text { shock and maintain supply chain } \\
\text { function }\end{array}$ & Persistence, robustness & $\begin{array}{l}\text { Multiple equilibria, } \\
\text { stability at a supply } \\
\text { chain level }\end{array}$ \\
\hline $\begin{array}{l}\text { Socio-ecological } \\
\text { resilience }\end{array}$ & $\begin{array}{l}\text { Self-organising: interplay between } \\
\text { disturbance, reorganising, sustaining } \\
\text { and developing i.e. developing } \\
\text { through adaptive capacity }\end{array}$ & $\begin{array}{l}\text { Transformability, } \\
\text { learning, innovation }\end{array}$ & $\begin{array}{l}\text { Integrated systems } \\
\text { feedback, cross-chain } \\
\text { dynamic interactions }\end{array}$ \\
\hline
\end{tabular}

Table 2. Concepts of resilience (Adapted from Folke, 2006) 
491 Table 3: Resilience indicator framework with indicator categories by type and 492 characteristic (Adapted from Bourlakis et al. 2014)

\begin{tabular}{|c|c|c|c|}
\hline \multirow[t]{2}{*}{ Indicator } & \multicolumn{3}{|c|}{ Characteristic } \\
\hline & Economic & Environmental & Social \\
\hline Efficiency & $\begin{array}{l}\text { Indicators relating to } \\
\text { costs, margins and } \\
\text { profitability or return on } \\
\text { capital employed. }\end{array}$ & $\begin{array}{l}\text { Indicators relating to } \\
\text { resource efficiency, waste } \\
\text { reduction, and carbon or } \\
\text { water footprint. }\end{array}$ & $\begin{array}{l}\text { Indicators relating to worker } \\
\text { welfare and management of } \\
\text { human capital e.g. staff } \\
\text { turnover, productivity per } \\
\text { person. }\end{array}$ \\
\hline Flexibility & $\begin{array}{l}\text { Indicators relating to the } \\
\text { capability to provide } \\
\text { individual service to } \\
\text { customers e.g. } \\
\text { differentiated stock } \\
\text { keeping units (SKU), } \\
\text { meeting changes in order } \\
\text { levels or timings, } \\
\text { minimising storage costs. }\end{array}$ & $\begin{array}{l}\text { Indicators relating to } \\
\text { environmental flexibility } \\
\text { include the ability to irrigate } \\
\text { crops if rainfall is } \\
\text { insufficient, to change what } \\
\text { type of forage is produced } \\
\text { on the farm in the event of } \\
\text { inclement weather. }\end{array}$ & $\begin{array}{l}\text { Indicators relating to worker } \\
\text { training and degree of } \\
\text { flexibility e.g. multiple skills } \\
\text { so can undertake more than } \\
\text { one task. Degree of } \\
\text { permanent versus contract } \\
\text { staff if the fruit crop is late, } \\
\text { orders are reduced from the } \\
\text { retailer. }\end{array}$ \\
\hline Responsiveness & $\begin{array}{l}\text { Indicators relating to } \\
\text { customer service, } \\
\text { distribution and delivery } \\
\text { costs. }\end{array}$ & $\begin{array}{l}\text { Indicators relating to } \\
\text { growing of new varieties } \\
\text { adapted to climate variation, } \\
\text { growing varieties that can } \\
\text { tolerate more salt, less } \\
\text { rainfall in a given region. }\end{array}$ & $\begin{array}{l}\text { Indicators relating to animal } \\
\text { welfare or labour standards } \\
\text { e.g. reactivity to livestock } \\
\text { mortality, livestock lameness, } \\
\text { or health challenges. } \\
\text { Responses to worker welfare } \\
\text { issues. }\end{array}$ \\
\hline Product quality & $\begin{array}{l}\text { Indicators relating to } \\
\text { compliance with product } \\
\text { specifications e.g. carcase } \\
\text { quality, intrinsic } \\
\text { characteristics of fresh } \\
\text { produce. }\end{array}$ & $\begin{array}{l}\text { Indicators relating to } \\
\text { environmental performance } \\
\text { e.g. shelf-life, } \\
\text { biodegradable or less } \\
\text { environmentally intensive } \\
\text { packaging. }\end{array}$ & $\begin{array}{l}\text { Indicators relating to extrinsic } \\
\text { production standards e.g. } \\
\text { reduced stocking density, } \\
\text { extensive production methods } \\
\text { and consideration of worker } \\
\text { conditions e.g. Fair Trade. }\end{array}$ \\
\hline
\end{tabular}


Table 4. Strategic resilience factors (Adapted from Caiazza and Volpe, 2015; Caiazza et al. 2014; Bourlakis et al. 2014; Delmas and Burbano, 2011; Muthuri et al. 2006; Elliott et al. 2002; Ackoff 1990; Mintzberg 1978)

\begin{tabular}{|c|c|c|c|}
\hline \multirow[t]{2}{*}{ Factors } & \multirow{2}{*}{$\begin{array}{c}\text { External influences } \\
\text { Executive level } \\
\end{array}$} & \multicolumn{2}{|c|}{ Internal influences } \\
\hline & & Organisational level & $\begin{array}{c}\text { Individual level } \\
\end{array}$ \\
\hline $\begin{array}{l}\text { Values based } \\
\text { dynamics }\end{array}$ & $\begin{array}{ll}\text { Pressure from } \\
\text { - } & \text { Non-market actors (legislation, regulators and regulatory } \\
& \text { environment and non- governmental organisations); } \\
\text { - } & \text { Market actors (consumers, investors and competitors); } \\
\text { - } & \text { New challenges; } \\
\text { - } & \text { Historic legacies; } \\
\text { Community groups }\end{array}$ & $\begin{array}{ll}\text { Pressure from: } \\
\text { - Organisational structure; } \\
\text { - } \quad \text { Organisational culture and sub-cultures; } \\
\text { - } \quad \text { Degree of organisisational inertia; } \\
\text { - Hew organisational challenges; and } \\
\text { Historic legacies. } \\
\end{array}$ & $\begin{array}{l}\text { Psychological and cognitive pressure include: } \\
\text { - Narrow decision framing; } \\
\text { - Oyperbolic intertemporal discounting; and } \\
\text { This could be due to bias. } \\
\text { information on which decisions are based. }\end{array}$ \\
\hline $\begin{array}{l}\text { Supply chain } \\
\text { dynamics }\end{array}$ & $\begin{array}{ll}\text { Pressure from: } \\
\text { - Demand/supply dynamics; } \\
\text { - Externally driven processes such as transport, communication } \\
\text { and infrastructure; and } \\
\text { - Externally driven controls including supply chain protocols, } \\
\text { policies, procedures, systems and assumptions. }\end{array}$ & $\begin{array}{l}\text { Pressure from: } \\
\text { - Internally driven processes including } \\
\text { communication and infrastructure; and } \\
\text { Internally driven controls including protocols, } \\
\text { policies, procedures, and systems. }\end{array}$ & $\begin{array}{l}\text { Pressure from: } \\
\text { - Internally driven processes operating at the } \\
\text { individual level including communication and } \\
\text { infrastructure; and } \\
\text { - Internally driven controls operating at the } \\
\text { individual level including protocols, policies, } \\
\text { procedures, and systems. }\end{array}$ \\
\hline $\begin{array}{l}\text { Strategic } \\
\text { leadership }\end{array}$ & $\begin{array}{cl}\text { Drives: } & \\
\text { - } & \text { Leadership at Executive level through stakeholder } \\
& \text { expectations; } \\
\text { - } & \text { Organisational operating system (external drivers); and } \\
\text { - } & \text { Change management (at executive level). } \\
\end{array}$ & $\begin{array}{cl}\text { Drives: } & \\
- & \text { Leadership at managerial level; } \\
\text { - } & \text { Organisational operating system (internal drivers); } \\
& \text { and } \\
\text { - } & \text { Change management at managerial level } \\
\end{array}$ & $\begin{array}{cl}\text { Drives: } & \\
\bullet & \text { Leadership at personal level; } \\
- & \text { Organisational operating system (internal } \\
& \text { drivers); and } \\
\bullet & \text { Change management at a personal level. } \\
\end{array}$ \\
\hline $\begin{array}{l}\text { Decision making } \\
\text { leadership }\end{array}$ & $\begin{array}{ll}\text { Drives: } & \\
\text { - } & \text { Normative decisions (values and impact and decisions that } \\
\text { create value); } \\
\text { - Policies and principles (rules and formulation of values for the } \\
\text { organisation and in turn product and service value; } \\
\text { - Strategic decisions (focus on growth and issues that have an } \\
\text { overarching organisational impact); and } \\
\text { Tactical, operational decisions (focus on efficiency and cost) } \\
\text { or those issues reported annually to shareholders. }\end{array}$ & $\begin{array}{cl}\text { Drives: } & \\
\text { - } & \text { Normative decisions (cultural and internal values); } \\
\text { - } & \text { Policies and principles (internal); } \\
& \text { htrategic decisions (internally focused issues that } \\
\text { - } & \text { Tactical, operanisational impact); } \\
\text { - } & \text { and cost); and } \\
\text { Tactical planning (operational, short-term goals) }\end{array}$ & $\begin{array}{cl}\text { Drives: } & \\
\text { - } & \text { Normative decisions (cultural and internal } \\
& \text { values); } \\
\text { - } & \text { Policies and principles (internal); } \\
\text { - } & \text { Strategic decisions (internally focused issues that } \\
\text { - } & \text { have an organisational impact); } \\
\text { - } & \text { Tactical operational decisions (focus on personal } \\
\text { - Tactical planning (personal, short-term goals). } \\
\end{array}$ \\
\hline $\begin{array}{l}\text { Use of } \\
\text { performance } \\
\text { indicators }\end{array}$ & $\begin{array}{l}\text { Externally driven from the need for regulatory compliance or } \\
\text { market pressures to improve productivity through developing } \\
\text { measures to drive efficiency, flexibility, responsiveness and } \\
\text { product quality. }\end{array}$ & $\begin{array}{l}\text { Internally driven from the need for regulatory } \\
\text { compliance or market pressures to improve } \\
\text { operational productivity through developing } \\
\text { measures to drive efficiency, flexibility, } \\
\text { responsiveness and product quality. }\end{array}$ & $\begin{array}{l}\text { Internally driven from the need for regulatory } \\
\text { compliance or market pressures to improve } \\
\text { personal productivity through developing } \\
\text { measures to drive efficiency, flexibility, } \\
\text { responsiveness and product quality. }\end{array}$ \\
\hline
\end{tabular}




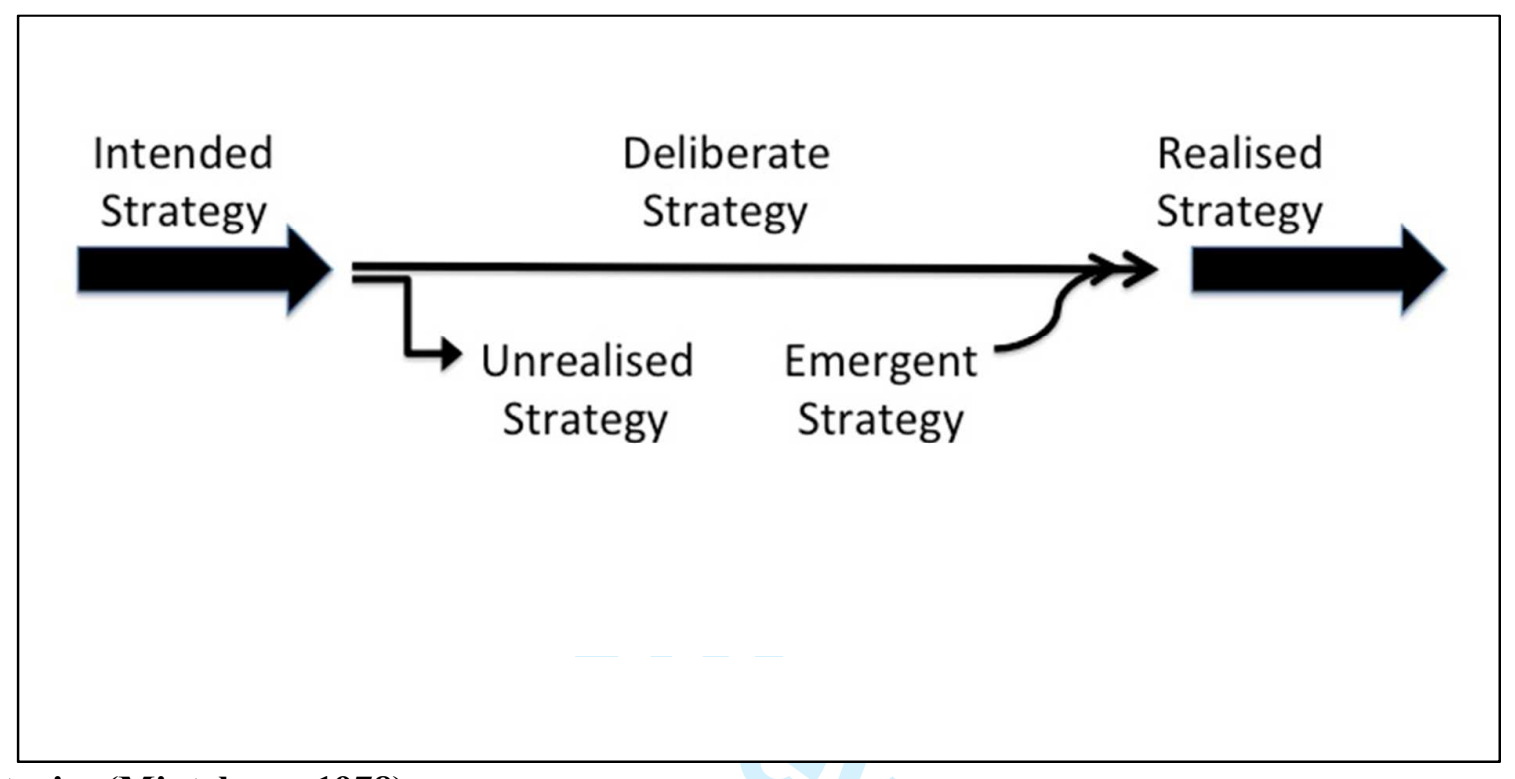

599 Figure 1. Types of Strategies (Mintzberg, 1978) 


\begin{tabular}{|c|c|c|c|c|}
\hline $\begin{array}{l}\text { External supply chain } \\
\text { risks }\end{array}$ & $\begin{array}{c}\text { Internal } \\
\text { organisational risks }\end{array}$ & Ready & Respond & Recover \\
\hline $\begin{array}{l}\text { Natural global disasters } \\
\text { affecting suppliers / } \\
\text { neighbouring countries e.g. } \\
\text { crop failure, drought, war etc. }\end{array}$ & $\begin{array}{l}\text { Natural local disasters } \\
\text { e.g. flood, snowstorm, } \\
\text { fire etc. }\end{array}$ & $\begin{array}{l}\text { Alternative approved ingredient and service suppliers, appropriate } \\
\text { stock levels of key ingredients; weather forecasting, alternative } \\
\text { approved packing, processing or storage facilities. }\end{array}$ & $\begin{array}{l}\text { BCM plan in place. Crisis response management team take } \\
\text { action according to agreed protocols; introduction of new } \\
\text { production plans to avoid productivity loss and minimise } \\
\text { disruption. }\end{array}$ & \multirow{6}{*}{$\begin{array}{l}\text { Continuous } \\
\text { improvement at } \\
\text { ready and } \\
\text { respond sections } \\
\text { to ensure quick } \\
\text { recovery or } \\
\text { change product } \\
\text { mix so that } \\
\text { continuity can be } \\
\text { maintained. } \\
\text { Review efficacy } \\
\text { of strategies and } \\
\text { procedures } \\
\text { employed and } \\
\text { update as } \\
\text { necessary. } \\
\text { Develop new } \\
\text { protocols, } \\
\text { adaption } \\
\text { strategies, } \\
\text { training } \\
\text { programmes as } \\
\text { required. }\end{array}$} \\
\hline $\begin{array}{l}\text { Technological accidents and } \\
\text { infrastructure threats (e.g. } \\
\text { accidents occurring at } \\
\text { suppliers' farms / processing } \\
\text { plant, transportation, } \\
\text { communication breakdown, } \\
\text { loss of data, technical } \\
\text { knowledge). }\end{array}$ & $\begin{array}{l}\text { Technological accidents } \\
\text { in own processing plant, } \\
\text { loss of data, technical } \\
\text { knowledge, } \\
\text { communication between } \\
\text { organisational centres. }\end{array}$ & $\begin{array}{l}\text { Alternative approved ingredient and service suppliers, appropriate } \\
\text { stock levels of key ingredients; Predetermined agreement for other } \\
\text { organisations even competitors to contract pack product until } \\
\text { problem is addressed, clean-up and respond standard operating } \\
\text { procedures (SOPs), alternative transport and distribution procedures } \\
\text { in place, information back-up, recovery and retrieval procedures } \\
\text { developed and ready to implement. }\end{array}$ & $\begin{array}{l}\text { BCM plan in place. Crisis response management team take } \\
\text { action according to agreed protocols; Clean-up / repair } \\
\text { technological accidents and approval protocols for } \\
\text { production to recommence; reduce production of particular } \\
\text { products and alternative supply mechanisms put in place to } \\
\text { avoid productivity loss. Implement information recovery } \\
\text { and retrieval procedures. }\end{array}$ & \\
\hline $\begin{array}{l}\text { Infectious animal diseases } \\
\text { (diseases affecting importing / } \\
\text { exporting countries, } \\
\text { competitors) e.g. avian } \\
\text { influenza, swine fever, foot } \\
\text { and mouth. }\end{array}$ & $\begin{array}{l}\text { Infectious diseases } \\
\text { (diseases affecting } \\
\text { suppliers' farms) e.g. } \\
\text { avian influenza, swine } \\
\text { fever, foot and mouth. }\end{array}$ & $\begin{array}{l}\text { Infectious disease continuity plans developed and annually tested, } \\
\text { emergency procedures developed and tested. Predetermined } \\
\text { agreement for alternative suppliers and markets so supply could be } \\
\text { diverted to source from other regions or suppliers. }\end{array}$ & $\begin{array}{l}\text { BCM plan in place. Crisis response management team take } \\
\text { action according to agreed protocols; Source from different } \\
\text { suppliers/ countries if disease outbreak is identified. } \\
\text { Implement alternative food products if possible to ensure } \\
\text { markets are not lost to competitors. Work with regulatory } \\
\text { requirements in terms of movement restrictions etc. until } \\
\text { lifted. }\end{array}$ & \\
\hline $\begin{array}{l}\text { Food fraud and wider food } \\
\text { crime incl. terrorism, boycott. }\end{array}$ & $\begin{array}{l}\text { Food fraud and food } \\
\text { crime including food } \\
\text { tampering, substitution } \\
\text { adulteration. }\end{array}$ & $\begin{array}{l}\text { Undertake TACCP assessment and develop response plan. Consider } \\
\text { wider potential for food crime associated with products sold e.g. with } \\
\text { high value foods, ethnic or specific culture foods. Identify "at-risk" } \\
\text { products that require specific monitoring. Horizon scan for emerging } \\
\text { and re-emerging food crime hazards. Review security procedures on } \\
\text { a routine basis. Develop a plan for alternative suppliers. Implement } \\
\text { employee screening and training programmes. }\end{array}$ & $\begin{array}{l}\text { BCM plan in place. Crisis response management team take } \\
\text { action according to agreed protocols; Implement controls } \\
\text { identified within TACCP Plan or equivalent. Isolate product } \\
\text { and implement product withdrawal or recall. Source from } \\
\text { different suppliers, investigate reason behind food } \\
\text { tampering and include law enforcement agencies where } \\
\text { required. }\end{array}$ & \\
\hline $\begin{array}{l}\text { Food safety incidents / } \\
\text { outbreaks / product recall. }\end{array}$ & $\begin{array}{l}\text { Food safety incidents / } \\
\text { outbreaks/ contamination } \\
\text { from own processing } \\
\text { plant. }\end{array}$ & $\begin{array}{l}\text { Undertake food safety risk assessment including HACCP assessment } \\
\text { and develop response plan. Determine risk to vulnerable groups. } \\
\text { Develop traceability and product recall and withdrawal procedures } \\
\text { and test these procedures on a routine basis. Horizon scan for } \\
\text { emerging and re-emerging food safety hazards. }\end{array}$ & $\begin{array}{l}\text { BCM plan in place. Crisis response management team take } \\
\text { action according to agreed protocols; Implement controls } \\
\text { identified within HACCP Plan or equivalent. Isolate product } \\
\text { and implement product withdrawal or recall. Source from } \\
\text { different suppliers, investigate reason behind food safety } \\
\text { incident and include regulatory and law enforcement } \\
\text { agencies where required. Undertake sampling and } \\
\text { laboratory testing. }\end{array}$ & \\
\hline $\begin{array}{l}\text { Market and pricing } \\
\text { strategies. }\end{array}$ & $\begin{array}{l}\text { Market and pricing, } \\
\text { economic crisis. }\end{array}$ & $\begin{array}{l}\text { Financial budgeting and planning including financial contingency } \\
\text { plans such as agreed extension to overdraft. Horizontal } \\
\text { collaboration to ensure market and price security (Leat and } \\
\text { Revoredo-Giha, 2013). }\end{array}$ & $\begin{array}{l}\text { Modify products to address constraints where possible. } \\
\text { Market / promote alternative products to address } \\
\text { fluctuating food prices/ availability. }\end{array}$ & \\
\hline
\end{tabular}

Figure 2. 3Rs (ready, respond and recovery) strategic resilience risk assessment framework for food supply chain 


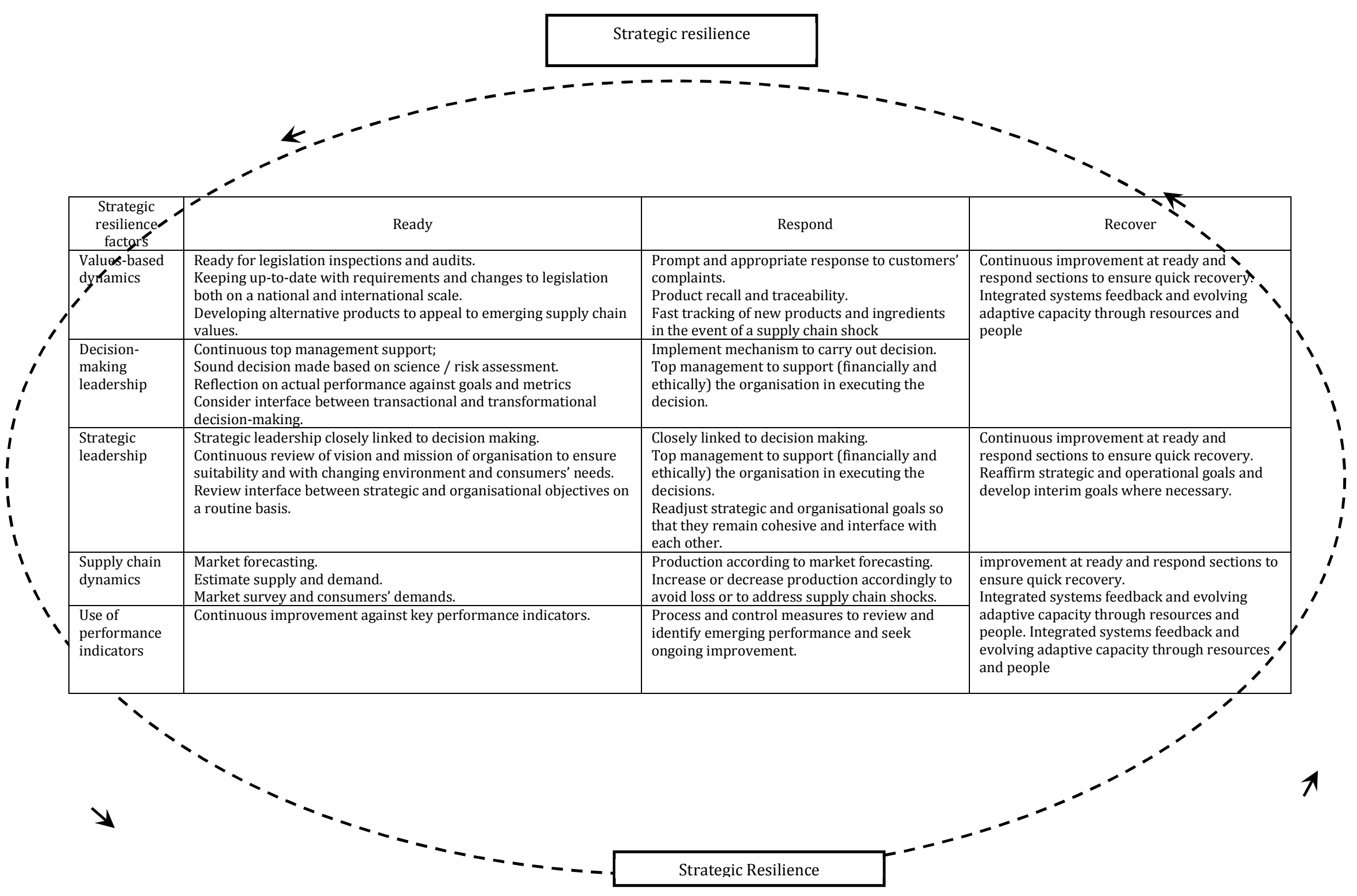


Figure 3. Strategic Resilience Indicator Framework incorporating values, decision-making, strategic, supply and performance factors into the $3 R s$ 